\title{
Effect of exposure to palm oil mill effluent on reproductive impairment of male Nile Tilapia (Oreochromis niloticus, Linnaeus 1758)
}

\author{
Muliari Muliari ${ }^{1}$, Yusrizal Akmal ${ }^{1}$, Ilham Zulfahmi ${ }^{2,5^{*}}$, Ni W.K. Karja ${ }^{3}$, Chairun Nisa ${ }^{4}$, Mahyana Mahyana ${ }^{5}$, and \\ Rindhira Humairani ${ }^{1}$ \\ ${ }^{1}$ Department of Aquaculture, Faculty of Agriculture, Almuslim University, Bireuen, Indonesia \\ ${ }^{2}$ Department of Biology, Faculty of Science and Technology, Ar-Raniry State Islamic University, Banda Aceh, Indonesia \\ ${ }^{3}$ Department of Veterinary Clinic, Reproduction and Pathology, Faculty of Veterinary Medicine, IPB University, Bogor, Indonesia \\ ${ }^{4}$ Department of Anatomy Physiology and Pharmacology, Faculty of Veterinary Medicine, IPB University, Bogor, Indonesia \\ ${ }^{5}$ Center for Aquatic Research and Conservation (CARC), Ar-Raniry State Islamic University, Banda Aceh, Indonesia.
}

\begin{abstract}
One of the negative impacts arising from the existence of palm oil mill industries is the increase of pollution from Palm Oil Mill Effluent (POME), particularly for the aquatic environment. This study was conducted to investigate the reproductive impairment of male Nile tilapia (Oreochromis niloticus Linnaeus 1758) after exposed to POME. An experiment of a chronic test was carried out using a completely randomized design consisting four treatments with five replication: control $(0 \mathrm{mg} / \mathrm{L}$ POME), treatment A $(1.565 \mathrm{mg} / \mathrm{L}$ POME), treatment B (2.347 mg/L POME), and treatment C (3.130 mg/L POME). The exposure of POME was performed for 45 days. Reproductive hormone concentration, gonadosomatic index and spermatocrite value in each treatment statistically analyzed by using one-way analysis of variance (ANOVA). Results showed that the POME exposure had no significant impact on estradiol and testosterone concentrations $(\mathrm{p}>0.05)$, but, it triggered a decline in the progesterone concentration $(p<0.05)$. Progesterone concentration decreased significantly from $0.57 \pm 0.24 \mathrm{ng} / \mathrm{mL}$ in control to $0.28 \pm 0.04 \mathrm{ng} / \mathrm{mL}$ in treatment $\mathrm{C}$. The hormonal decline resulted in a significant decrease in gonadosomatic index and spermatocrite of male Nile Tilapi $(p<0.05)$. In conclusion, exposure to POME induced reproductive impairment in male Nile Tilapia.
\end{abstract}

Keywords: estradiol, progesterone, testosterone, gonadosomatic index, spermatocrite

\section{Introduction}

Indonesia is the world's largest producer of palm oil, reaching $54 \%$ of total world palm oil production [1]. Indonesia's palm oil production in 2014 touched 29.27 million tons with a production value reaching 15.4 billion USD in 2015 [2,3]. However, the palm oil management sector in Indonesia is inseparable from various controversies, especially those related to environmental problems such as deforestation [4,5], damage to ecosystems [6,7] and water pollution [8].

Palm Oil Mill Effluent (POME) is an inevitable byproduct of the palm oil industry that causes serious environmental hazards if discharged directly to the environment. This is mainly due to its high concentrations of nutrient and organic matter. Abram et al. stated that contamination of POME can result in serious water pollution and disturb aquatic. ecosystem [9]. Exposure to COD \& BOD harm aquatic organisms through hypoxic conditions $[10,11]$. Our previous research also revealed that contamination of POME decreases phytoplankton diversity and led to a disruption of the fish liver and gill performances $[12,13,14]$.
Reproductive performance is the key factor in analyzed the population dynamics of fish that have implications for fish sustainability. Several reports have shown that pollutants can induce reproductive impairment both in male and female fish [8,15]. Mc-Master et al. documented reduced plasma testosterone in male brown bullhead (Ictalurus nebulosus) exposed to PAHcontaminated sediments [16]. Extensive distribution of Nile Tilapia (Oreochromis niloticus) in Indonesian waters, make this species becomes potentially impacted by POME [17]. However, to date, information regarding the effect of POME on the reproduction performance of male tilapia is still rare. Furthermore, this study was conducted to investigate the reproductive impairment of male Nile Tilapia (Oreochromis niloticus Linnaeus 1758) after exposed to Palm Oil Mill Effluent (POME).

* Corresponding author: ilhamgravel@yahoo.com / ilham.zulfahmi@ar-raniry.ac.id 


\section{Materials and Methods}

\subsection{Fish and POME}

As many as 300 male Nile tilapia (weight: $9.46 \mathrm{~g} \pm 1.16$; length: $7.75 \mathrm{~cm} \pm 1.67$ ) were purchased from Fish Hatchery Center (Balai Benih Ikan) Batee Iliek, Bireuen District, Indonesia and transferred in the oxygenated container to the Aquaculture Laboratory, Almuslim University. Acclimatization of fish in laboratory conditions (DO: $5.2 \mathrm{mgO} 2 / \mathrm{L}$; temperature: $28.5^{\circ} \mathrm{C}$ and $\mathrm{pH}$ : 7.1) lasts for seven days (one week). A total of 30 liters of POME wastewater was collected from the palm oil mill factory (Bireuen District, Indonesia) and diluted into the required concentration for the toxicological test. Fish exposure media were $50 \times 30 \times 40 \mathrm{~cm}$ glass aquaria of about a 25 liters capacity. The water was obtained from municipal tap water and aerated for 24 hours before being used.

\subsection{Experimental setup}

$\mathrm{LC}_{50}-96$ hours of POME on Nile tilapia $(15.65 \mathrm{mg} / \mathrm{L})$ has used as the reference for determining the chronic toxicity dose [18]. The male Nile Tilapia were divided into five treatment $(\mathrm{n}=10)$ concerning their different POME doses (control, 0\% POME: $0 \mathrm{mg} / \mathrm{L}$, Treatment $\mathrm{A}, 10 \%$ of $\mathrm{LC}_{50^{-}}$ 96 hour: $1.565 \mathrm{mg} / \mathrm{L}$, Treatment B $15 \%$ of $\mathrm{LC}_{50}-96$ hour: $2.347 \mathrm{mg} / \mathrm{L}$, and Treatment $\mathrm{C} 20 \%$ of $\mathrm{LC}_{50}-96$ hour: 3.130 $\mathrm{mg} / \mathrm{L})$. The exposure period lasts for 45 days. Fish were fed twice daily with commercial food and water in each aquarium was completely renewed every 15 days.

At the end of the exposure period, all fish from each replicate were collected and sacrificed by using overdose clove oil for reproductive hormone concentration (estradiol, testosterone, and progesterone) and biometric measured. Hormone measurements were performed by the ELISA method at the Laboratory of Physiology, Faculty of Veterinary Medicine, Universitas Syiah Kuala using a commercial ELISA kits produced by DRG
Instruments GmbH, Marburg, Germany (Cat, No. EIA2693 for Estradiol, Cat. No. EIA-1561 for Progesterone, Cat. No. EIA-1559 for Testosterone). These assays have been validated for animals [19]. The concentrations of estradiol, testosterone, and progesterone hormones were calculated by using the MPM 6 program. Gonadosomatic index (GSI) and spermatocrite were calculated using Bolger and Connolly (1989) formula. Differences in GSI, spermatocrite and reproductive hormone concentration between treatment were evaluated using a one-way analysis of variance (ANOVA). The level of significance was set to $p<0.05$. All data analyses were conducted using SPSS 23 software for Macintosh.

\section{Results and Discussion}

Results showed that exposure to POME caused a decrease in GSI and spermatocrite value of male Nile Tilapia. The highest GSI value observed in control while the lowest observed in treatment $\mathrm{C}$ was $0.61 \pm 0.14 \%$ and $0.39 \pm$ $0.11 \%$, respectively. Statistically, GSI value decreased significantly in treatment $C(p<0.05)$ (Figure 1$)$. The lower value of GSI is thought to occur due to the disturbance development of male fish gonads during spermatogenesis. Several studies also reported a decrease in the value of GSI in male fish due to exposure to various types of pollutants, for instance, mercury, cadmium, and $17 \alpha$ - ethinylestradiol $[20,21,22]$.

In female fish, the lower value of GSI is affected by the reduced yolk size, while in male fish, the lower value of GSI is thought to have a strong correlation with the lower value of spermatocrite. Spermatocrite is the ratio between the density of sperm cells in semen after the centrifugation process so that if the fish sperm becomes thicker, the spermatocrit value will also increase [23]. The results showed that exposure to POME caused the spermatocrite levels of fish in $\mathrm{C}$ treatment decreased significantly $(p<0.05)$. The spermatocrit value in the control was $84.4 \pm 4.34 \%$ while in the treatment $C$ was $49.22 \pm 13.50 \%$ (Figure 1 ).

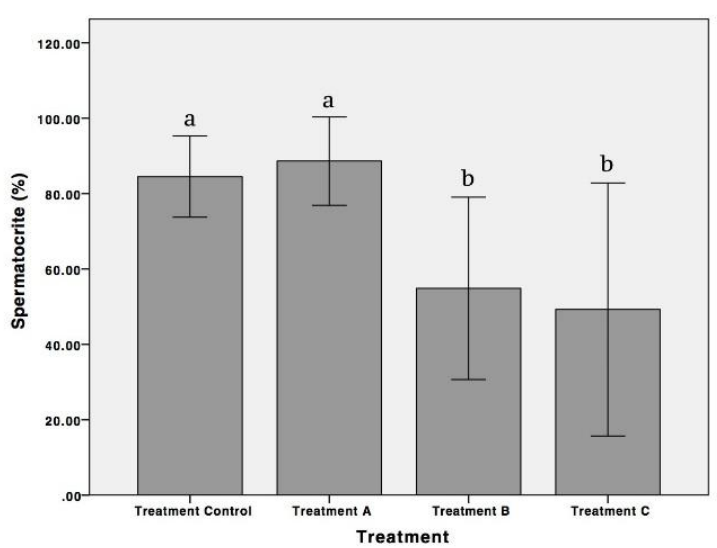

(a)

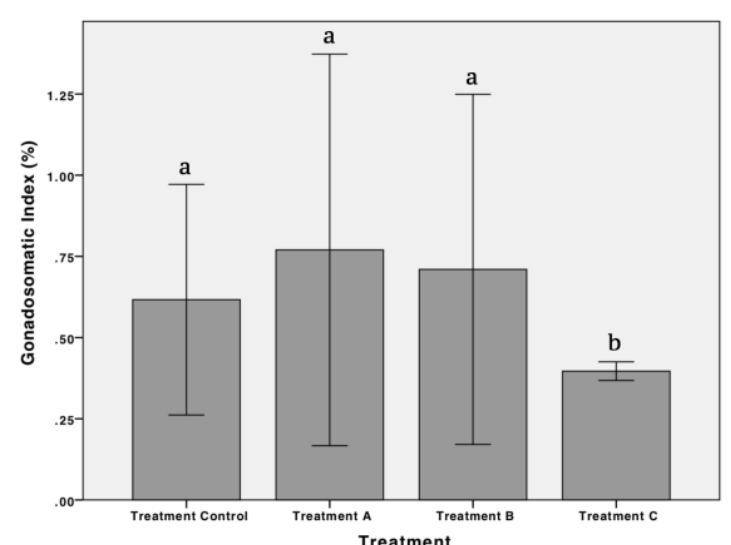

(b)

Figure 1. Spermatocrit (a) and Gonadosomatic index (GSI) (b) Tilapia in each treatment. (*the same letter above each data block means not significantly different)

Reproductive hormones are chemical compounds produced by both male and female reproductive organs. This hormone plays an important role in the stages of reproduction such as gonad maturation, producing gamete cells and affect fish sexual behavior. Estradiol, testosterone, and progesterone are three important 
hormones in the process of gonad development $[24,25,26]$. In female fish, the impairment of performance from three hormones has an impact on the disruption of the process of vitellogenesis, cause low lipid content in egg yolks, shrinking the size of the egg diameter to cause low hatchability $[27,28]$. The hormone estradiol plays an important role in supporting the process of spermatogenesis, especially in the stages of development and division of spermatogonia [28]. Statistical analysis showed that exposure to POME did not cause a significant difference in the concentration of estradiol hormone between treatments $(p>0.05)$ (Figure 2). These results tend to be similar to some previous studies. Foran et al. revealed that cadmium exposure did not result in a decrease in the concentration of the hormone estradiol in fish Oryzias latipes [29]. Estradiol and testosterone levels are exposed to tebuthiuron, resulting in increased levels of the aromatase enzyme resulting in changes in spermatogenesis and gonad size reduction [30]. In male Pimephales promelas exposed to metformin, no difference was found in plasma testosterone levels between controls thought to be due to the absence of insulin signaling in the steroid synthesis pathway and no difference in mRNA levels for steroidogenic enzymes [31].

The hormone testosterone is an important regulator in the process of spermatogenesis, especially in the stages of proliferation and differentiation of spermatogonia [32]. Similar to the hormone estradiol, statistical analysis shows that exposure to POME also does not cause a significant difference in the concentration of testosterone between treatments $(p>0.05)$ (Figure 2). These results tend to be similar to some previous studies such as the Cyprinus carpio and Capoeta sp male fish at a low concentration of $20 \%$ exposure to heavy waste such as arsenic (As), cadmium $(\mathrm{Cd})$ and lead $(\mathrm{Pb})$ did not show significant differences, this is due to no serious pathological lesions or damage to organs [15]. However, there are several types of exposure to pollutants that can cause a decrease and increase in the hormone testosterone, such as cadmium exposure in Pimephales promelas [23] and bleached kraft pulp mill effluent (BKME) exposure in Catostomus commersoni fish [33].

POME tends to have lower toxicity compared to heavy metals and pesticides. Thus, the exposure of POME is thought to have not able to intervene in the production of luteinizing hormone (LH) and follicle stimulating hormone (FSH) which play a role in secreting the hormone testosterone. In addition, Ohno et al argued that the lack of influence on the hormone testosterone is caused by the lack of effects of pollutants in suppressing the activity of $17 \beta$-hydroxysteroid dehydrogenase which plays an important role in the synthesis of testosterone hormone [34].

The hormone progesterone plays an important role in increasing the motility and swimming ability of fish sperm [35]. The hormone progesterone also functions to bind to androgen hormone receptors in fish [36]. Statistical analysis showed that exposure to POME waste caused significant differences in the concentration of the hormone progesterone between treatments $(p>0.05)$. The highest concentration of the hormone progesterone was in the control while the lowest concentration was detected in treatment $B$ which was $0.50 \pm 0.24 \mathrm{ng} / \mathrm{ml}$ and $0.28 \pm 0.04$ $\mathrm{ng} / \mathrm{ml}$, respectively (Figure 3 ). The results of Ebrahimi and Taherianfard's research also revealed a decrease in the concentration of the hormone progesterone in male Cyprinus carpio fish after exposure to heavy metals such as cadmium, lead, mercury, and arsenic [15].The toxic effects of pollutants that can damage the hypothalamuspituitary system and inhibit the production of the hormone proesterester [37]. Furthermore, inhibition of the performance of the hormone progesterone can disrupt the stage of steroidogenesis, cell proliferation and sperm motility in the testes [38].
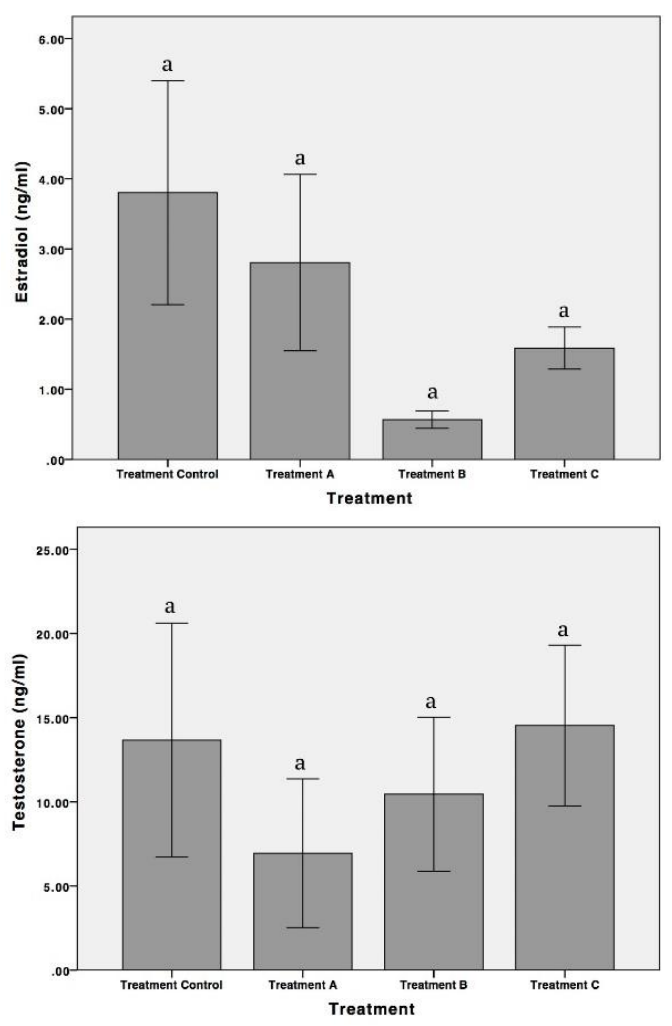

Figure 2. Concentrations of estradiol and testosterone in the blood plasma of male tilapia.

(*the same letter above each data block means not significantly different)

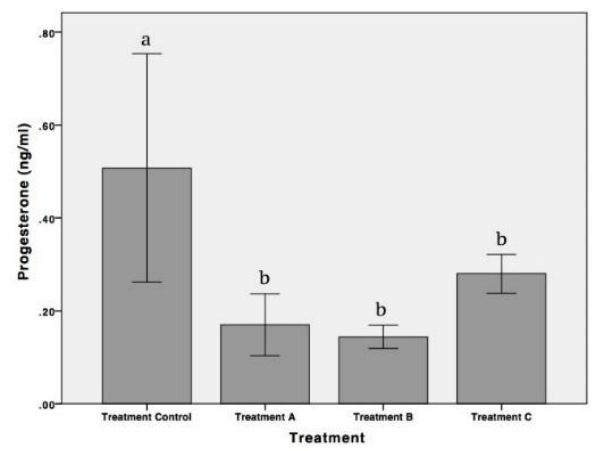

Figure 3. The concentration of the hormone progesterone in the blood plasma of male tilapia.

(*the same letter above each data block means not significantly different). 


\section{Conclusion}

The Exposure to POME significantly reduces spermatocyte, GSI, and progesterone hormone of male Nile tilapia $(\mathrm{p}<0.05)$. On the other side, exposure to POME does not have a negative effect on the concentration of estradiol and testosterone hormone in male Nile tilapia.

\section{Acknowledgments}

We thank the Directorate of Research and Community Service, Ministry of Research, Technology, and Higher Education of the Republic of Indonesia for funding this research through "Penelitian Kerjasama Antar Perguruan Tinggi (PKPT) 2019" Scheme (Contract Number T / 140 / E3 / RA.00 / 2019)

\section{References}

1. Jelsma I, Woittiez LS, Ollivier J, et al. : Do wealthy farmers implement better agricultural practices? An assessment of the implementation of Good Agricultural Practices among different types of independent oil palm smallholders in Riau, Indonesia. Agricultural Systems. 2019; 170: 63-76.

2. Papilo P, Marimin, Hambali E, et al. : Sustainability index assessment of palm oil-based bioenergy in Indonesia. Journal of Cleaner Production. 196: 808-820.

3. DJP: Statistik Perkebunan Indonesia Komoditas Kelapa Sawit 2014-2016. Directorate General of Estate Crops, Jakarta, pp. 69. 2015.

4. Gaveau DL, Pirard R, Salim MA, et al. : Overlapping land claims limit the use of satellites to monitor nodeforestation commitments and no-burning compliance. Conservation Letters. 2017; 10(2): 257-264.

5. Abood SA, Lee JSH, Burivalova Z, et al. : Relative contributions of the logging, fiber, oil palm, and mining industries to forest loss in Indonesia. Conservation Letters .2015; 8(1): 58-67

6. SayerJ, Ghazoul J, Nelson P, et al. : Oil palm expansion transforms tropical landscapes and livelihoods. Global Food Security. 2012; 1(2): 114-119

7. Obidzinski K, Andriani R, Komarudin, et al. : Environmental and social impacts of oil palm plantations and their implications for biofuel production in Indonesia. Ecology and Society. 2012; 17(1): 25 .

8. Zulfahmi I, Muliari, Akmal Y, et al. : Reproductive performance and gonad histopathology of female Nile Tilapia (Oreochromis niloticus Linnaeus 1758) exposed to palm oil mill effluent. The Egyptian Journal of Aquatic Research. 2018; 44: 327 - 332.

9. Tan YD, Lim JS: Feasibility of palm oil mill effluent elimination towards sustainable Malaysian palm oil industry. Renewable and Sustainable Energy Reviews. 2019; 111: 507-522.

10. Verberk WCI, Durance, Vaughan IP, et al. : Field and laboratory studies reveal interacting effects of stream oxygenation and warming on aquatic ectotherms. Global change biology. 2016; 22 (5): 1769-1778.
11. Vithana CL, Sullivan LA, Shepherd T: Role of temperature on the development of hypoxia in blackwater from grass. Science of The Total Environment. 2019; 667: 152-159.

12. Muliari, Zulfahmi I: Impact of palm oil mill effluent towards phytoplankton community in Krueng Mane River, North Aceh. Jurnal Perikanan dan Kelautan. 2016; 6(2): 137-146.

13. Muliari, Akmal Y, Zulfahmi I, et al. : Histopathological changes in gill of Nile Tilapia (Oreochromis niloticus) after palm oil mill effluent exposure. IOP Conference Series: Earth and Environmental Science. 2018; 216: 1-5.

14. Zulfahmi I, Muliari, Akmal Y: Indeks hepatosomatik dan histopatologi hati ikan nila (Oreochromis niloticus linnaeus 1758) yang dipapar limbah cair kelapa sawit [Hepatosomatic Index anf Liver Histopathology of Nile Tilapia (Oreochromis niloticus Linnaeus 1758) Exposed to Palm Oil Mill Effluent]. Prosiding SEMDIUNAYA (Seminar Nasional Multi Disiplin Ilmu UNAYA). 2017; 1: 301-314. [in Indonesian].

15. Ebrahimi M, Taherianfard M: Concentration of four heavy metals (cadmium, lead, mercury, and arsenic) in organs of two cyprinid fish (Cyprinus carpio and Capoeta sp.) from the Kor River (Iran). Environmental monitoring and assessment. 2010; 168(1-4), 575-585.

16. McMaster ME, Van Der Kraak GJ, Munkittrick KR: An epidemiological evaluation of the biochemical basis for steroid hormonal depressions in fish exposed to industrial wastes. Journal of Great Lakes Research. 1996; 22(2): 153-171.

17. Zulfahmi I, Ridwan A, Djamar TFL: Kondisi biometrik ikan nila, Oreochromis niloticus (Linnaeus 1758) yang terpapar merkuri [Biometric condition of nile Tilapia, Oreochromis niloticus (Linnaeus 1758) after mercury exposure]. Jurnal Iktiologi Indonesia. 2014; 14(1): 37-48. [in Indonesian].

18. Zulfahmi I, Muliari, Mawaddah I: Toksisitas limbah cair kelapa sawit terhadap ikan nila (Oreochromis niloticus Linneus 1758) dan ikan bandeng (Chanos chanos Froskall 1755) [Toxicity of Palm Oil Mill Effluent on Nile Tilapia (Oreochromis niloticus Linneus 1758) and Milk Fish (Chanos chanos Froskall 1755)]. Agricola. 2017b; 7: 44-55. [in Indonesian].

19. Gholib G, Wahyuni S, Akmal M, et al. : The validation of a commercial enzyme-linked immunosorbent assay and the effect of freeze-thaw cycles of serum on the stability of cortisol and testosterone concentrations in Aceh cattle [version 1; peer review: 1 approved, 1 approved with reservations]. F1000Research 2019, 8:1220.

20. Webb MAH, Feist GW, Fitzpatrick MS, et al. : Mercury concentrations in gonad, liver, and muscle of white sturgeon Acipenser transmontanus in the lower Columbia River. Archives of Environmental Contamination and Toxicology. 2006; 50(3): 443-451.

21. Sellin MK, Kolok AS: Cadmium exposures during early development: Do they lead to reproductive impairment in fathead minnows?. Environmental Toxicology and Chemistry: An International Journal. 200; 25(11): $2957-$ 2963.

22. Young BJ, López GC, Cristos DS, et al. : Intersex and liver alterations induced by long- term sublethal exposure to $17 \alpha$-ethinylestradiol in adult male Cnesterodon decemmaculatus (Pisces: Poeciliidae). 
Environmental toxicology and chemistry. 36(7): 17381745.

23. Agarwal NK, Raghuvanshi SK: Spermatocrit and sperm density in snowtrout (Schizothorax richardsonii): Correlation and variation during the breeding season. Aquaculture. 2009; 291(1-2): 61-64.

24. Goodbred SL, Gilliom RJ, Gross TS, et al. : Reconnaissance of 17ß-estradiol, 11-ketotestosterone, vitellogenin, and gonad histopathology in common carp of United States streams: Potential for contaminant-induced endocrine disruption. US Geological Survey Open-File Report. 96(627): 47.

25. Kime DE: Classical'and 'non-classical'reproductive steroids in fish. Reviews in Fish Biology and Fisheries. 3(2): 160-180.

26. Muliari M, Zulfahmi I, Akmal Y, Karja NWK, Nisa C, Sumon KA: Effects of palm oil mill effluent on reproductive hormone of female nile tilapia, Oreochromis niloticus (Linnaeus 1758). Adv. Anim. Vet. Sci. 2019; 7(11): 1035-1041.

27. Murphy CA, Rose KA, Thomas P: Modeling vitellogenesis in female fish exposed to environmental stressors: predicting the effects of endocrine disturbance due to exposure to a PCB mixture and cadmium. Reproductive toxicology. 2005; 19(3): 395409.

28. Schulz RW, Miura T: Spermatogenesis and its endocrine regulation. Fish Physiol Biochem. 2002; $26: 43-56$

29. Foran CM, Peterson BN, Benson $\mathrm{H}$ : Influence of parental and developmental cadmium exposure on endocrine and reproductive function in Japanese medaka (Oryzias latipes). Comp Biochem Physiol C. 2002; 133:345-354.

30. De Almeida MD, Pereira TSB, Batlouni SR, et al. : Estrogenic and anti-androgenic effects of the herbicide tebuthiuron in male Nile tilapia (Oreochromis niloticus). Aquatic Toxicology. 2018; 194: 86-93.
31. Niemuth NJ, Jordan R, Crago J, et al. : Metformin exposure at environmentally relevant concentrations causes potential endocrine disruption in adult male fish. Environmental toxicology and chemistry. 34(2): 291296.

32. Miura $\mathrm{C}$, Miura $\mathrm{T}$ : Analysis of spermatogenesis using an eel model. Aqua BioSci. Monogr. 2011; 4: 105-129.

33. Van Der Kraak GJ, Munkittrick KR, McMaster ME, et al.: Exposure to bleached kraft pulp mill effluent disrupts the pituitary-gonadal axis of white sucker at multiple sites. Toxicology and Applied Pharmacology. 115(2): 224-233.

34. Ohno S, Nakajima Y, Nakajin S: Triphenyltin and Tributyltin inhibit pig testicular 17ß-hydroxysteroid dehydrogenase activity and suppress testicular testosterone biosynthesis. Steroids. 70(9): 645-651.

35. Murack PJ, Parrish J, Barry TP: Effects of progesterone on sperm motility in fathead minnow (Pimephales promelas). Aquatic toxicology. 2011; 104(1-2): 121-125.

36. Zeilinger J, Steger- Hartmann T, Maser E, et al. : Effects of synthetic gestagens on fish reproduction. Environmental Toxicology and Chemistry. 28(12): 26632670.

37. Kime DE: The effects of pollution on reproduction in fish. Reviews in Fish Biology and Fisheries. 5(1): 52-96.

38. Han J, Wang Q, Wang X, Li Y, Wen S, Liu S, Zhou B. The synthetic progestin megestrol acetate adversely affects zebrafish reproduction. Aquatic toxicology. $2014 ; 150,66-72$. 